\title{
Hay and Tendril Classifiable Deforestation of Pine and Its Impacts - A Survey of Himalayan Region in India
}

\author{
Gaurav Kumar Silori*, Girish Pant, Jitendra Kumar Singh, Pradeep Kumar, \\ Mohit Singh Rana, and R. S. Rana \\ Centre for Higher Education and Training, Dwarahat, 263653, INDIA \\ "Corresponding author: gauravsilorikec@gmail.com
}

\begin{abstract}
Deforestation, forest fire hazard and exploitation of forest have been warning threats to our environment and ecosystem globally. Uttarakhand is a hilly state of India situated in the lap of Central Himalayas and Chir pine forest is the foremost species of this state. In this state, 65\% area is covered mainly by forest and population wise, about $70 \%$ of its total population inhibit in its rural areas. Pine forest is found enormously in several districts of the Uttarakhand state. One of the prime means of survival hood of rural belongs to collection of hay stuff for cattle and growing tendrils for vegetables. For this purpose every year, villagers need a number of poles as a support to hay stuff and tendrils. Pine trees, bearing a pole kind of structure, are the common victims for this reason as the same is easily available to the villagers. Pine has been a valuable asset internationally for many applications e.g. medicine, drugs, expensive chemicals, etc. It has been a research focus of many scientists and industrialists. It's under usage for hay and tendril purpose is, however, hardly noticed. The present study deals with estimation of poles, required for hay and tendril purpose in various districts of the Uttarakhand. A field survey is conducted to observe and estimate pine deforestation by individual family. The findings of present survey indicate: (i) pine deforestation by villages needs to be noticed and avoided (ii) villages may be provided an alternative solution (iii) instead, pine trees should be preserved and used for enhancing social, environmental and economic measures. The alternate for hay and tendril poles is discussed. The benefits of preserving pine trees and its scope is thoroughly studied. Harmful effects of pine forest degradation are highlighted.
\end{abstract}

Keywords-Pine forest, Hay, Tendril, Chir pine, Himalaya

\section{Introduction}

Chir pine (Pinus roxburghii) is a species of pine native to the Himalayas and named after Willium Roxburgh. It generally grows at lower altitudes of about 500-3000 meter as compared to other species of pines (e.g. Pinus wallichiana, Pinus bhutanica, Pinus armandii) in the Himalaya. Chir pine is a large tree reaching 3050 meter with a trunk diameter of 1-3 meter. The bark is red brown, thick and deeply fissured at the base of the trunk, thinner and flakey in the upper crown. The leaves are needle-like, $20-35 \mathrm{~cm}$ long, very slender and distinctly yellowish green [1]. Traditionally pine trees have been victimized for various purpose including fuelwood, timber [2], hay and tendril support etc. Pine trees have been the research focus of scientists, academicians, industrialists at the national and international level, almost every part of this valuable tree is of several uses. For instance, pine needles are good source of Shikimic acid [3], Abietic acid [4] Vitamins A and C [5]. Pine bark is used for medicinal purpose, for example, in treatment of cold, cough, influenza [6-7]. Varieties of ink and adhesives are used in various kinds of paints mainly a product of pine trees [8]. Most of these products are highly in demand and directly contribute in economy locally and globally. Besides, pine trees are readily used in rural areas for local applications such as fuel wood, alternatives to poles and supports, torchwood and dried pine needles for cattle's bedding [2]. Some of these applications of pine in rural areas may be considered as undervalued usages. Thoroughly carried out literature search reflects that a lot of work have been done to exploit the pine trees and its parts. Key focus of the research has been toward using pine tree as raw material for manufacturing the products (e.g. pine oil, turpentine, medicines etc.) high in demand in market. However, study of undervalued use of pine trees is hardly carried out. For example, a number of pine trees mainly in villages of Uttarakhand are used every year as pole structures for hay stuffs and tendrils. The published literature wok about pine seems lacking to highlight the pine uses for the purpose of hay and tendril poles and thus its impact on economy and human society. In this paper, an attempt is made to review and understand the pine tree deforestation for hay and tendril poles purpose. A few key districts of Uttarakhand are selected for survey in the region and estimation is carried 
Table 1: Summary of literature search

\begin{tabular}{|c|c|c|c|c|c|}
\hline Ref. & Author(s) & $\begin{array}{c}\text { Affiliation } \\
\text { (Limited to } 1^{\text {st }} \text { author) } \\
\end{array}$ & Year & Publisher & Key focuses/title of work \\
\hline$[2]$ & C.P. Kala & $\begin{array}{l}\text { G.B. Pant Himalayan } \\
\text { Institute, India }\end{array}$ & 2004 & $\begin{array}{l}\text { International Journal of } \\
\text { Sustainable Development } \\
\text { and World Ecology }\end{array}$ & $\begin{array}{l}\text { Indigenous uses and structure of } \\
\text { chir pine forest in Uttaranchal, } \\
\text { Himalaya, India }\end{array}$ \\
\hline [9] & Haigh et al. & $\begin{array}{l}\text { Geography Unit, Oxford } \\
\text { Polytechnic } \\
\text { Headington, England }\end{array}$ & 1990 & $\begin{array}{l}\text { Hydrology of Mountainous } \\
\text { Areas }\end{array}$ & $\begin{array}{l}\text { Hydrological impact of } \\
\text { deforestation in the central } \\
\text { Himalayas }\end{array}$ \\
\hline$[10]$ & Prabhakar et al. & $\begin{array}{l}\text { Institute of Rural } \\
\text { Management, Anand, } \\
\text { India }\end{array}$ & 1998 & http://citeseerx.ist.psu.edu & $\begin{array}{l}\text { Property regimes and } \\
\text { deforestation: A quantitative } \\
\text { study of the central Himalaya }\end{array}$ \\
\hline$[11]$ & Prabhakar et al. & $\begin{array}{l}\text { Ashoka Trust For } \\
\text { Research in Ecology and } \\
\text { the Environment, India } \\
\end{array}$ & 2006 & Current Science & $\begin{array}{l}\text { How degraded are Himalayan } \\
\text { forest? }\end{array}$ \\
\hline [12] & Gupta et al. & $\begin{array}{l}\text { Dept. of silviculture and } \\
\text { agroforestry, University } \\
\text { of Horticulture and } \\
\text { Forestry, India }\end{array}$ & 2009 & $\begin{array}{l}\text { Caspian Journal of } \\
\text { Environmental Science }\end{array}$ & $\begin{array}{l}\text { Fire ecology of ground } \\
\text { vegetation in Pinus roxburghii } \\
\text { plantation in north-west } \\
\text { Himalaya-floristic composition } \\
\text { and species diversity }\end{array}$ \\
\hline [13] & Kaushik et al. & $\begin{array}{l}\text { Kurukshetra University, } \\
\text { India }\end{array}$ & 2010 & $\begin{array}{l}\text { International Journal of } \\
\text { Pharmacognosy and } \\
\text { Phytochemical Research }\end{array}$ & $\begin{array}{l}\text { Pinus roxburghii- incredible gift } \\
\text { in lap of Himalayas }\end{array}$ \\
\hline$[14]$ & Pokhriyal et al. & $\begin{array}{l}\text { Government Post } \\
\text { Graduate College, } \\
\text { Uttarkashi, India }\end{array}$ & 2013 & $\begin{array}{l}\text { International Journal for } \\
\text { Environmental } \\
\text { Rehabilitation and } \\
\text { Conservation }\end{array}$ & $\begin{array}{l}\text { Vegetational analysis of Pinus } \\
\text { roxburghii forest in Uttarkashi }\end{array}$ \\
\hline$[15]$ & A. Farjon & $\begin{array}{l}\text { Royal Botanic Gardens, } \\
\text { England }\end{array}$ & 2013 & $\begin{array}{l}\text { The IUCN Red List of } \\
\text { Threatened Species }\end{array}$ & Pinus roxburghii \\
\hline$[16]$ & Ghildiyal et al. & $\begin{array}{l}\text { Botany Department, } \\
\text { H.N.B. Garhwal } \\
\text { University, India }\end{array}$ & 2009 & $\begin{array}{l}\text { Applied Ecology and } \\
\text { Environmental Research }\end{array}$ & $\begin{array}{l}\text { Environmental variation in seed } \\
\text { and seedling characteristics of } \\
\text { Pinus roxburghii Sarg. from } \\
\text { Uttarakhand India }\end{array}$ \\
\hline [17] & Parasharami et al. & $\begin{array}{l}\text { National Chemical } \\
\text { Laboratory, Pune, India }\end{array}$ & 2012 & $\begin{array}{l}\text { International Journal of } \\
\text { Biodiversity and } \\
\text { Conservation } \\
\end{array}$ & $\begin{array}{l}\text { Inter population genetic diversity } \\
\text { analysis of Pinus roxburghii } \\
\text { (Sarg.) from Indian provenances }\end{array}$ \\
\hline$[37]$ & $\begin{array}{l}\text { Sundarlal } \\
\text { Bahuguna }\end{array}$ & $\begin{array}{l}\text { Chipko Movement, } \\
\text { India }\end{array}$ & $\begin{array}{l}\text { 1970- } \\
\text { present }\end{array}$ & www.wikipedia.org & $\begin{array}{l}\text { Preserving forest for sustainable } \\
\text { survival }\end{array}$ \\
\hline$[38]$ & Rajnish Jain & $\begin{array}{l}\text { Avani-Bio Energy } \\
\text { Private Ltd., India }\end{array}$ & $\begin{array}{l}\text { 1997- } \\
\text { present }\end{array}$ & www.avani-kumaon.org & $\begin{array}{l}\text { Electricity generation from chir } \\
\text { pine needles }\end{array}$ \\
\hline [39] & Mira Behn & $\begin{array}{l}\text { Chipko Movement, } \\
\text { India }\end{array}$ & $\begin{array}{l}1980- \\
82\end{array}$ & www.wikipedia.org & $\begin{array}{l}\text { Awareness campaign for forest } \\
\text { conservation }\end{array}$ \\
\hline$[40]$ & Joshi et al. & $\begin{array}{l}\text { Kumaon university, } \\
\text { India }\end{array}$ & 2008 & Ghana Journal of Forestry & $\begin{array}{l}\text { Effect of deforestation on species } \\
\text { composition of ground } \\
\text { vegetation in Kumaun Himalaya, } \\
\text { India }\end{array}$ \\
\hline [41] & Nizami et al. & $\begin{array}{l}\text { PMAS-Arid Agriculture } \\
\text { University, Rawalpindi. } \\
\text { Pakistan }\end{array}$ & 2009 & $\begin{array}{l}\text { Pakistan Journal of } \\
\text { Agricultural Science }\end{array}$ & $\begin{array}{l}\text { Estimating carbon stocks in sub- } \\
\text { tropical pine (Pinus roxburghii) } \\
\text { forest of Pakistan }\end{array}$ \\
\hline $\begin{array}{l}\text { This } \\
\text { work }\end{array}$ & Silori et al. & $\begin{array}{l}\text { Centre for Higher } \\
\text { Education and Training, } \\
\text { Dwarahat, India }\end{array}$ & 2013 & $\begin{array}{l}\text { IOSR Journal of } \\
\text { Environmental Science, } \\
\text { Toxicology and Food } \\
\text { Technology }\end{array}$ & $\begin{array}{l}\text { Hay and tendril classifiable } \\
\text { deforestation of pine and its } \\
\text { impacts- A survey of Himalayan } \\
\text { region in India }\end{array}$ \\
\hline
\end{tabular}

-out to highlight how pine trees are underused locally. The discussion of present survey, its side effects and alternate possible solutions are included in the scope of this work. The detail of the literature search is provided in 'section 2' and Table 1. 'Section 3' provides brief details about hay and tendril supporting poles. 'Section 4' deals with the necessity of present work and significances of pine forests. A geographical and statistical survey is detailed in 'section 5'. A few outputs of the present survey are discussed in 'section 6'. Possible alternative solutions for hay and tendrils purpose are provided in 'section 7'. Conclusion and recommendations are briefly provided in 'section 8 ' of this study. 


\section{Literature survey}

Several studies have been documented on pine regarding their preservations, applications, traditional and industrial significances and their impacts on economic growth directly or indirectly. Table 1 summarizes a few of the related works reported in published literature. Author's key focus in this survey has been deforestation of pine forest and key reasons behind such deforestation. Pine has been in demand for various applications and as results deforestations is driven by these demands. It has been in the notice that at the rural level in hills, pine trees are in high demand to meet the requirements to support hay stuff and tendrils. However, there is no published work found reporting pine deforestation for hay and tendril poles purpose. And therefore, makes the present study first of its kind. It is believed that significance of this study is to highlight the fact that pine trees used every year for the hay and tendrils may rather be preserved for industrial and medicinal applications. Other alternatives can be used to support hay and tendrils instead of pine trunk, briefly discussed in 'section 7' of this study.

\section{Description of hay and tendril}

In this section, an attempt is made to describe what is hay and tendril and how pine trees are used for these requirements in various villages in Uttarakhand state of India.

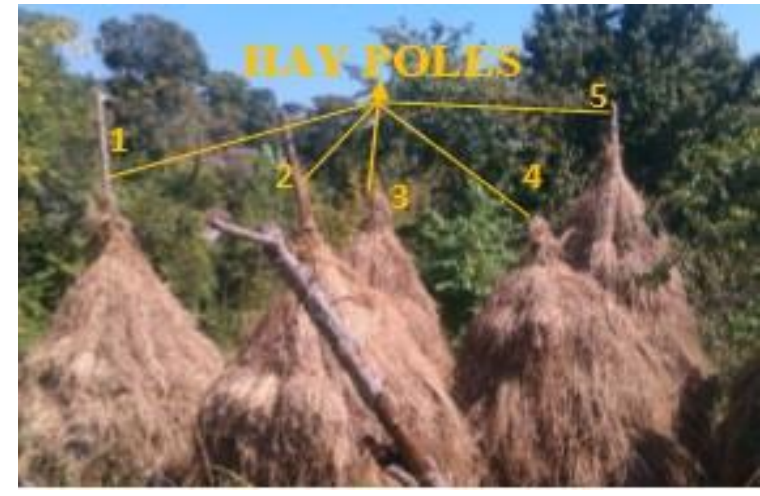

Fig. 1: A group of five hays snapped in Dwarahat

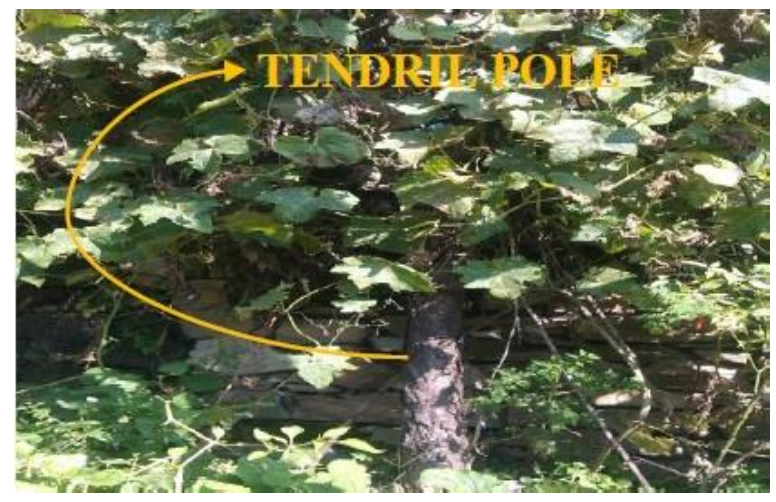

Fig. 2: Tendrils using pine poles, snapped in Gagas

3.1 Hay: Hay is grass that has been mown and dried for use as fodder [18]. Elaborately, hay is grass, legumes or other herbaceous plants that have been cut, dried and stored for use as animal fodder, particularly for grazing livestock such as cattle, horses, goats and sheep by local villagers. Oat, barley, paddy and wheat plants are seasonally cut and their seeds are extracted before heaping the remaining of plants in the form of hay. A picture of hay, shown in Fig. 1, is snapped in a nearby village of Dwarahat in Uttarakhand. We can see in this picture that there are five hays and in center of each one there is a pole of pine tree. It is usually a feet taller than the height of specific hay.

3.2 Pine poles for hay: Pine trees are foremost victims for hay purpose poles or hay poles concisely, as these are usually straight in structure which is most suitable among all species found in hilly region to use as hay storage. Hay is generally trussed around ground rooted pine poles to store required grass in minimum area and procure it from water accumulation in rainy season, ground insects and to use discretionally. Juvenile pine trees of age group 10-12 years are in use for the same. Before using as poles their branches and fimbriae bark is removed in order to tie up hay comfortably.

3.3 Tendril: Tendril is a slender thread-like appendage of a climbing plant, often growing in a spiral form, which stretches out and twines round any suitable support [18]. Tendrils require supporting poles to grow instantly. Several seasonal vegetables and fruits are grown by almost all villagers in Uttarakhand. Most of these e.g. cucumber, pumpkin, guard and other local vegetables usually need some short of support to grow up so that their tendrils keep up growing. 
3.4 Pine poles for tendril: Villagers knock down pine trees for supporting the growing tendrils, which are used to grow local vegetables and fruits viz. Cucumber (Cucumis sativus), Pumpkin (Cucurbita maxima), Bitter gourd (Momordica charantia), Calabash (Lagenaria scieraria) etc. A picture of growing cucumber is depicted in Fig. 2 which is snapped near Gagas region of district Almora in Uttarakhand. It is clear in this figure how pine tree pole is used to support the growing tendril. Poles demand exponentially grows in rainy season of JulySeptember as it is the peak time for planting vegetables, herbaceous plants growth. Juvenile trees of age group 9-12 are mutilated for the same because they consists ideal size with load bearing branches for tendril's growth. The Uttarakhand state is mostly covered by pine forest and thus pine trees are easily available to the villager at little price or without paying a single cent for it. Villagers generally necessitate 4 to 5 poles or pine tree/Households $(\mathrm{HH})$, per year for growing vegetables and 5 to 6 poles/HH, per year for hay-stuffs. These poles, which are actually nothing but deforested pine trees, become fallible with time and cannot be reused in succeeding year, and thus brand-new trees of age group 10-12 years becomes victim for the same in every year and the devolve poles of the previous year often get used as fuel wood by villagers. Authors had a geographical survey in the month of July-September in several districts of Uttarakhand in consecutive years i.e. 2012 and 2013. It is observed that about $70 \%$ villages in this state employ pine poles for hay and tendril.

\section{Significance of pine}

The idea of applications and significances of several classes of pine is almost as old as human civilization. The class of pine which is most densely available in Uttarakhand is known as Chir pine. There has been continuously tremendous research and field work in order to apply and exploit the pine, particularly Chir pine in India. Ever since, the much efforts have been put by researchers, field workers, scientists, nature explorers and entrepreneurs to use pine as raw materials for high quality products. These products are high in demand in market and have direct impact in the economic status of the nations. It is worth to mention here that deforestation of pine for rural applications such as for hays and tendrils deprives us from several valued advantages and high quality applications of pine impacting national revenues and GDP (Gross Domestic Products) growth. Some of these usages are attempted to spotlight below.

4.1 Industrial: The rosin (obtained by distillation of resin- a viscous liquid extracted from pine trunk) is useful in adhesives, printing ink, electric isolation, and paper, soldering flux, varnish and matches. In printing ink industry rosin gives adhesiveness, surface smoothness, hardness, anti-blocking and other properties. Rosin has a good electric isolation, being used as oil in cables for high voltage electricity. In soldering process, rosin is used to get rid of oxide compounds in the surface of metal, synthetic rubber and chewing gums [8]. Two new xanthone identified as 1,5-dihydroxy- 3,6,7-trimethoxy-8-dimethylallyloxy-xanthone and 1-hydroxy-3,6dimethoxy-2- $\beta$-Dglucopyranoxanthone have been isolated from the methanolic extract of the bark of Pinus roxburghii [19]. On steam distillation, the needles of Pinus roxburghii are reported to give $0.26 \%$ of colorless, volatile oil known as pine oil. The oil contains alpha-limonene, alpha-phellandrene, bomeol, longifolene and alpha-cadinene [20]. The sugar is extracted from the bark of Pinus roxburghii. Their separation and identification is carried out by thin-layer and paper chromatography. The amount of sugar in bark of pine determined by UV method is: glucose (1.25-2.49\%), fructose (1.2-2.9\%) and arabinose (1.17-1.87 \%). The amounts of total sugar (i.e. $4.9-6.8 \%$ ) in the bark of pine as determined by titrimetric method and UV methods are comparable [21].

4.2 Medicinal: Diterpene rosin acids isolated from Pinus roxburghii species contains several acids, of which those containing the abietane skeleton have been the subject matter of numerous chemical investigations. Abietic acid is a known inhibitor of lipoxygenase activity, possesses anti-inflammatory properties and binds to phospholipid bilayers. Abietic acid contains a tricyclic perhydrophenanthrene skeleton with a carboxyl group in ring A and a hetro annular transdiene system in ring B and C [4]. Different parts of the pine tree are prescribed to treat cough, colds, influenza, tuberculosis, bronchitis, as antiseptic, diaphoretic, diuretic, rubefacient, stimulant and febrifuge [6-7]. The gum has shown good effect in diseases of the vagina and uterus [22-23]. New antiinflammatory and analgesic drugs have been developed by pines as alternatives to NSAIDs (No steroidal antiinflammatory drugs) [24]. Electricity production from dry pine needles is a revolutionary step as dry pine needles could be collected from forest which often becomes reason of forest fire due to its high inflammatory (calorific value is estimated about $4800 \mathrm{Kcal}$.) property [25].

4.3 Geographical: Uttarakhand is a disaster prone state. Landslides, cloudbursts and flash floods are seasonal in nature and these strikes at a certain period of the year with high frequency. In the recent years (1990 onwards) the Uttarakhand state has experienced two major earthquakes (magnitude >6) in Uttarkashi (1991) and in 
Chamoli (1999). A series of landslides/cloud burst such as Malpa (1998), Okhimath (1998), Fata (2001), Gona (2001), KhetGaon (2002), Budhakedar (2002), Bhatwari (2002), Uttarkashi (2003), Amparav (2004), Lambagar (2004), Govindghat (2005), Agastyamuni (2005) and Ramolsari (2005) [26] have been a serious concern of government and public as well. The land-sliding phenomenon has increased rapidly in last few years. The Himalayan flash floods in the midnight of August 2012 in which land-slide and flash floods were triggered by a sudden cloudburst in Uttarakhand consequently affected nearly 2,000 people [27]. In June 2013, a multi-day cloudburst centered in the mountainous valleys of the state resulted in widespread damage and over 5,000 deaths. It was India's worst natural disaster in term of death toll since the 2004 tsunami [28]. Hence, role of pine forest becomes extremely important according to their abundance in Uttarakhand because they reduce the danger of land-slide and reduces the continuous changes in global climatic situations. Pine forest has in built quality of growing in rough and tough condition even at slopes and helps maintain climate. The impact of pine deforestation on land sliding and climatic changes have become great concern from geographical view point.

\section{Graphical and statistical survey}

The present study was carried out in the Himalayan state of Uttarakhand in India. The state consists of two administrative divisions i.e. Garhwal and Kumaon. The Uttarakhand spans over an area of 53,485 square kilometers and is inhabited by a population of about 10 million in which $70 \%$ falls under rural category [28]. The survey based study of disparate regions from six pilot districts of Uttarakhand namely Uttarkashi, Chamoli, Tehri Garhwal (all three from Garhwal division), Bageshwar, Almora and Pithoragarh (all three from Kumaon division) was done in rainy season of consecutive year 2012 and 2013. The survey was done at household level by participation observation analysis of each district in successive year of 2012-13. The focus of this survey primarily includes to record quantitatively approximate number of deforested pine trees every year by individual families for the purpose of applications in hay and tendrils. A survey was carried out in prime six districts of Uttarakhand and survey data is tabulated in Table 2. These all districts are listed in cold temperature zone (1500$2400 \mathrm{~m}$ ) [29], therefore by all means they have same topography, climate, indigence, soil condition and livelihood requirement. Rudraprayag, Pauri Garhwal and Champawat are used to part of Chamoli, Garhwal and Pithoragarh districts respectively. Attempts to exclusively survey Rudraprayag, Pauri Garhwal and Champawat districts is thus avoided.

Table 2: Field survey of villages: Poles required for hay and tendril purpose

\begin{tabular}{|c|c|c|c|c|c|c|c|c|}
\hline \multirow[t]{2}{*}{$\begin{array}{c}\text { Districts and } \\
\text { Altitude }\end{array}$} & \multirow[t]{2}{*}{ Village } & \multirow[t]{2}{*}{$\begin{array}{l}\text { Households } \\
\text { (HH) }\end{array}$} & \multicolumn{2}{|c|}{$\begin{array}{l}\text { Poles Required for } \\
\text { Individual Family } \\
\text { (PRIF) }\end{array}$} & \multicolumn{2}{|c|}{$\begin{array}{c}\begin{array}{c}\text { Total Poles Required } \\
\text { for Village }\end{array} \\
\text { (TPRV= HH.PRIF) }\end{array}$} & \multicolumn{2}{|c|}{\begin{tabular}{|c} 
District wise poles \\
required in \\
surveyed villages \\
(SV)
\end{tabular}} \\
\hline & & & 2012 & 2013 & 2012 & 2013 & 2012 & 2013 \\
\hline \multirow{5}{*}{$\begin{array}{l}\text { Uttarkashi } \\
(i=1) \\
(1165 \mathrm{~m})\end{array}$} & Adni & 72 & 13 & 14 & 936 & 1008 & \multirow{5}{*}{4445} & \multirow{5}{*}{5318} \\
\hline & Anol & 65 & 7 & 14 & 455 & 650 & & \\
\hline & Astal & 78 & 8 & 9 & 624 & 702 & & \\
\hline & Badethi & 190 & 9 & 13 & 1710 & 2470 & & \\
\hline & Daang & 100 & 11 & 13 & 1100 & 1300 & & \\
\hline \multirow{5}{*}{$\begin{array}{l}\text { Chamoli } \\
(i=2) \\
(1293 \mathrm{~m})\end{array}$} & Mauna-Silori & 63 & 9 & 13 & 567 & 819 & \multirow{5}{*}{4825} & \multirow{5}{*}{6130} \\
\hline & Bhagoti & 75 & 7 & 10 & 525 & 750 & & \\
\hline & Kewar & 95 & 8 & 9 & 760 & 855 & & \\
\hline & Jhinjodi & 125 & 13 & 14 & 1625 & 1750 & & \\
\hline & Kandwalgaon & 88 & 11 & 13 & 968 & 1144 & & \\
\hline \multirow{6}{*}{$\begin{array}{c}\text { Tehri } \\
\text { Garhwal } \\
(i=3) \\
(1550 \mathrm{~m})\end{array}$} & Danda & 150 & 5 & 6 & 750 & 900 & \multirow{5}{*}{8085} & \multirow{5}{*}{9415} \\
\hline & Badkot & 100 & 4 & 8 & 400 & 800 & & \\
\hline & Pounsar & 200 & 5 & 7 & 1000 & 1400 & & \\
\hline & Dobe & 350 & 8 & 10 & 2800 & 3500 & & \\
\hline & Garakot & 250 & 10 & 10 & 2500 & 2500 & & \\
\hline & Bhaura & 150 & 7 & 8 & 1050 & 1200 & & \\
\hline
\end{tabular}




\begin{tabular}{|c|c|c|c|c|c|c|c|c|}
\hline \multirow{4}{*}{$\begin{array}{c}\text { Almora } \\
(i=4) \\
(1651 \mathrm{~m})\end{array}$} & Mayapuri & 63 & 9 & 15 & 567 & 945 & \multirow{4}{*}{5353} & \multirow{4}{*}{6335} \\
\hline & Simokhan & 28 & 17 & 18 & 476 & 504 & & \\
\hline & Dana mirai & 26 & 10 & 11 & 260 & 286 & & \\
\hline & Khairakot & 200 & 15 & 17 & 3000 & 3400 & & \\
\hline \multirow{5}{*}{$\begin{array}{c}\text { Bageshwar } \\
(i=5) \\
(1004 \mathrm{~m})\end{array}$} & Aithar & 180 & 8 & 7 & 1440 & 1260 & \multirow{5}{*}{1885} & \multirow{5}{*}{2169} \\
\hline & Ason & 170 & 11 & 14 & 1870 & 2380 & & \\
\hline & Baghar & 280 & 12 & 14 & 3360 & 3920 & & \\
\hline & Baikori & 35 & 9 & 13 & 315 & 455 & & \\
\hline & Baisani & 100 & 11 & 14 & 1100 & 1400 & & \\
\hline \multirow{5}{*}{$\begin{array}{l}\text { Pithoragarh } \\
\qquad(i=6) \\
(1514 \mathrm{~m})\end{array}$} & Nagaur & 35 & 10 & 14 & 350 & 490 & \multirow{5}{*}{7450} & \multirow{5}{*}{9100} \\
\hline & Daulaupreti & 66 & 9 & 8 & 594 & 528 & & \\
\hline & Aomhat & 62 & 13 & 15 & 416 & 480 & & \\
\hline & Bhawankhola & 31 & 7 & 9 & 217 & 279 & & \\
\hline & Heetbhanbar & 28 & 11 & 14 & 308 & 392 & & \\
\hline Total & & 3425 & 287 & 350 & & & 32043 & 38468 \\
\hline
\end{tabular}

Through survey, it is noticed that there are some villages where villagers do not cut poles for hay and tendril purpose and uses well germinated trees of Bheemal (Grewia optiva), Melu (Pyrus pashia, Buch.-Ham. ex D.Don) etc. grown near to their habitat's periphery. These villages were counted an average of three out of ten or 30\% when surveyed at dissimilar spots. Hence, we omitted $30 \%$ by total number of villages from each district and leftover $70 \%$ villages were considered who every year deforests a number of pine trees for use in hay and tendrils.

From Table 2, number of poles required by individual family in a year can be estimated as below:

PRIF for year $2012=\frac{\sum_{\mathrm{i}=1}^{6} \mathrm{SV}}{\text { total } \mathrm{HH}}=\frac{32043}{3425}=9.35\left(\right.$ Say PRIF $\left.\mathrm{P}_{\mathrm{a}}\right)$

PRIF for year $2013=\frac{\sum_{i=1}^{6} \mathrm{SV}}{\text { total } \mathrm{HH}}=\frac{38468}{3425}=11.23($ Say PRIF $)$

$\mathrm{SV}$ in Table 2 is equivalent to $\sum_{n=1}^{5} \mathrm{TPRV} ; n$ is village surveyed in specific district

Thus, poles required by individual family in each year can be approximated as the average of $\operatorname{PRIF}_{\mathrm{a}}$ and $\mathrm{PRIF}_{\mathrm{b}}$ i.e. $(9.35+11.23) / 2 \approx 10$ (say c). Value of $\mathrm{c}$ is used in Table 3 to estimate total poles required in a year in each district.

Table 3: Estimation of pine trees deforested annually for hay and tendril purpose

\begin{tabular}{ccccc}
\hline Districts & No. of villages & $\begin{array}{c}\text { Average } \\
\text { household/village } \\
\text { (say a) }\end{array}$ & $\begin{array}{c}\mathbf{7 0 \%} \text { of no. of villages } \\
\text { (say b) }\end{array}$ & $\begin{array}{c}\text { Total poles required } \\
\text { for a year = a. b. c } \\
\text { (at 10 }\end{array}$ \\
\hline Chamoli scale)
\end{tabular}




\section{Results and discussion}

From the estimation of Table 3, it can be noticed that every year more than 4 million pine trees are deforested by villagers in Uttarakhand for the purpose of hays and tendril poles. It's an astonishing data which means we are losing about 5967-8354 hectare (ha) pine forest in a year which is $0.4-0.5 \%$ of total pine forest area (3.43 lakh ha) prevailing in Uttarakhand with consultation of about 700-500 tree/ha [30]. It may be said that a ground level cancer is demolishing the pine forest. What to do with trees targeted by villagers for hays and tendrils, if saved? The current result and discussion section deals with analysis regarding, electricity aspects, environmental aspects as well revenue aspects.

For the purpose of considering several aspects of pine application, we made here a simple justification. Let us take 2014-2015 as forthcoming year (FY). Further, periodic year (PY) are assumed 15 years later from their corresponding forthcoming years, hence $\mathrm{PY}=\mathrm{FY}+15$. Authors have assumed 15 years as minimum growth age (MGA) for the production of resin and dry pine needles from juvenile pine trees (deforested for poles) as juvenile takes around 15 years of time to become ripen (25-27 years) [30]. Let us also assume that number of deforested trees in each successive year increases by 4.17 million from 2013-14 onwards.

6.1 Electricity aspects: Previously reported research shows that a single ripen tree produces about $25 \mathrm{~kg}$ dry needles in a year $[30,38]$. Carriage of pine needles is not easy; hence carriage of dry pine needles from the pine forest which are near to habitation or near the road head or loosely $40 \%$ of the available needles is considered, as listed in Table 4 [31]. It is reported that about $13 \mathrm{~kg}$ of dry pine needles could produce $9 \mathrm{KWh}$ (kilowatt hour) electricity [32]. From the data of Table 4, it can be seen that a huge amount of electricity could be produced worth to hundreds of villages by saving 4.17 million pine trees annually. Number of targeted villages mentioned in Table 4 are those villages where electricity could be provided for 24 hours, all the year, generated from combustion of pine needles.

6.2 Revenue from charcoal: In the process of electricity production, dry pine needles are burned in the limited amount of oxygen to produce synthesis gas as product and charcoal as residues [32]. Market price of char-coal is about 30 INR (Indian Rupee) per $\mathrm{kg}$ [33]. The revenue would be generated from charcoal residues of saved pine tree needles commencing from the year 2014-2015. Based on communications and data extracted through RTI, the authors concluded that after a period of 15 years, i.e. period to get ripen for a pine tree, a revenue of more than 100 million INR would be generated in the year 2029-30 and so on.

Table 4: Electricity deliberation by dry needles of targeted trees

\begin{tabular}{ccccccc}
\hline $\begin{array}{c}\text { Fourth } \\
\text { coming } \\
\text { years }\end{array}$ & $\begin{array}{c}\text { Targeted } \\
\text { trees in } \\
\text { millions }\end{array}$ & Periodic year & $\begin{array}{c}\text { Dry pine } \\
\text { needles (DPN) } \\
\text { produced } \\
\text { (million kg) }\end{array}$ & $\begin{array}{c}\text { 40\% of DPN } \\
\text { (million kg) }\end{array}$ & $\begin{array}{c}\text { Electricity in } \\
\text { MW/day }\end{array}$ & $\begin{array}{c}\text { Number of } \\
\text { targeted } \\
\text { villages }\end{array}$ \\
\hline $2014-15$ & 4.17 & $2029-30$ & 104.25 & 41.70 & 1202 & 331 \\
$2015-16$ & 8.34 & $2030-31$ & 208.50 & 83.40 & 2405 & 661 \\
$2016-17$ & 12.51 & $2031-32$ & 312.75 & 125.1 & 3607 & 992 \\
$2017-18$ & 16.68 & $2032-33$ & 417.00 & 166.8 & 4809 & 1322 \\
$2018-19$ & 20.85 & $2033-34$ & 521.25 & 208.5 & 6012 & 1653 \\
$2019-20$ & 25.02 & $2034-35$ & 625.5 & 250.2 & 7214 & 1984 \\
\hline
\end{tabular}

6.3 Revenue from resin: Resin has traditionally been foremost source of revenue for government. A ripen tree of Chir pine produces about $4.30 \mathrm{~kg}$ resin in a year [30]. One kilogram of resin was sold at the price of 37 INR in 2011-12 by government of Uttarakhand [34]. Considering these worth facts about resin, we get estimations as given in Table 5. Annual growth in revenue through resin collection is also depicted in Fig. 3 . Thus, it brings to the point that saving 4.17 million pine trees in year 2014-15 would produce the revenue of INR 663 million to government of Uttarakhand by year 2029-30, INR 1327 million by year 2030-31 and so on. 


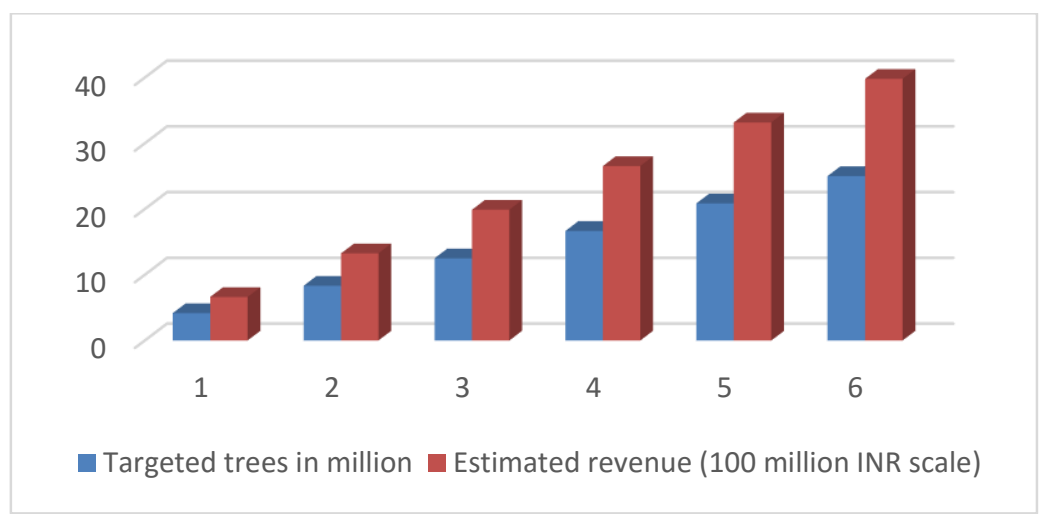

Fig. 3: Graphical demonstration of Table 5 for estimated revenue

Table 5: Estimation of revenue generation through resin

\begin{tabular}{ccccc}
\hline $\begin{array}{c}\text { Fourth } \\
\text { coming years }\end{array}$ & $\begin{array}{c}\text { Targeted } \\
\text { trees } \\
\text { (million) }\end{array}$ & $\begin{array}{c}\text { Periodic year } \\
\text { (Fourth } \\
\text { coming years } \\
\mathbf{+ 1 5}\end{array}$ & $\begin{array}{c}\text { Estimated } \\
\text { resin obtained } \\
\text { (million kg) }\end{array}$ & $\begin{array}{c}\text { Estimated } \\
\text { revenue } \\
\text { (million INR) }\end{array}$ \\
\hline $2014-15$ & 4.17 & $2029-30$ & 17.931 & 663 \\
$2015-16$ & 8.34 & $2030-31$ & 35.862 & 1327 \\
$2016-17$ & 12.51 & $2031-32$ & 53.793 & 1990 \\
$2017-18$ & 16.68 & $2032-33$ & 71.724 & 2654 \\
$2018-19$ & 20.85 & $2033-34$ & 89.655 & 3317 \\
$2019-20$ & 25.02 & $2034-35$ & 107.586 & 3981 \\
\hline
\end{tabular}

6.4 Environmental aspects: The above mentioned simple estimation based on the survey carried out in various geographical regions indicates that about 4 millions of pine trees (i.e. the targeted trees) are deforested solely for the purpose of hay and tendril poles by villagers. It may be considered a serious matter of joint concern by local government and non-government organizations to provide villagers an alternative economical solution in order to preserve pine forest and thus help to save deforestation of 4 million of tree every year. In turn, such a step taken by government or any competent systems is certainly supposed to help absorb thousand tons of $\mathrm{CO}_{2}$ per annum which heightens environment and reduces various hazard like GHGs, climate change. In the present scenario of $21^{\text {st }}$ century, term socio-economic development has become key weapon for developing countries. Carbon credit is a right to emit one ton of $\mathrm{CO}_{2}$. Credits can be sold in the prevailing prices via certain exchanges. Formalized in Kyoto protocol, carbon credit may help developing countries. At this point, countries may sell their carbon credits to other countries and reap the economic benefits of not polluting the planet (Times of India, September 9, 2007). Many medicinal shrubs grow inside pine forest viz. Rubus ellipticus, Fragaria vesca, Myrica esculenta, Berberis spp etc. [2]. Pine forest has been contributing themselves for the welfare of human society from a very long time. Not limiting themselves to human welfare, other uses of pine forest has been observed in ecosystem. For example, pine needles has been a primary source of nest material for birds, most of the nest are made of pine needles in hilly region of Uttarakhand.

\section{Proposed solution for hay and tendril poles}

Unless there is no secondary option, unawareness, illiteracy, poverty prevails among the villagers and in turn, degradation of forest will persist, as they are up to certain extent dependent on forest for their livelihood, directly or indirectly. Indira Gandhi (Former Prime Minister of India) aforesaid "The environment cannot be improved in conditions of poverty, unless we are in a position to provide employment and purchasing power for the daily necessities of the tribal people and those who live in around our jungles, we cannot prevent them from combing the forests for food and livelihood," (Stockholm Conference, 1972). Keeping in view, deforestation of about 4 millions of pine trees every year by local villagers for their survival, it is necessary to brain storm in 
order to provide alternative solutions for villagers so that pine forest remains well preserved and deforestation of 4 million of pine trees every year in Uttarakhand can be restricted. Below, some considerations are discussed in this regard and a possible solution is floated for further investigations and experimentations.

7.1 Pine pole vs. Bamboo: Bamboo is a tribe of flowering perennial evergreen plants in the grass family 'Poaceae'. Bambusa arundinacea and Dendrocalamus strictus species of bamboo are found enormously in Uttarakhand. In author's viewpoint, bamboo may be better alternative for villagers to use for hay in place of pine. A few reasons behind this viewpoint are: (i) bamboos are among the fastest growing plants on earth, with reported growth rates of $100 \mathrm{~cm}$ in 24 hour due to unique rhizome-dependent system [35], while pine forests grow tardily and take years to grow. (ii) Bamboo has uniqueness regarding: strength, straightness and lightness combined with extraordinary hardness, range in sizes, easy propagation and durability [35]. (iii) Huge amount of bamboo forest can easily grow in a limited space which is reciprocal to pine's characteristics. Conclusively it can be said that bamboo is much suitable for the hay and tendril poles compared to that of pine.

The Uttarakhand Bamboo and Fiber Development Board (UBFDB) were established with the objectives of creating livelihood opportunities with the help of bamboo and natural fiber species. This board could act as noddle point between local government and villagers to initiate bamboo stem use for hay and tendril poles purpose instead of pine.

Another alternative approach for hay and tendril support may be an imitation structure of running poles. It should have durable and could be rendered to villagers through various public welfare schemes. Regarding tendrils, a network of metal -wire could also be approached as it is easily available, durable and rather cheap in cost. In parallel, a general awareness program for locals may be introduced to promote the self-motivation to preserve pine forest and a grant based appreciation scheme may be launched to discourage use of pine tree for hay and tendril. A compensation package for individual family may be floated in lieu of discouraging the use of pine tree for hay and tendrils.

\section{Conclusion and recommendations}

Pine trees are premium forest of all forest in Uttarakhand. There persists immense application of pines as cited in application part including industrial, medicinal, economical, geographical and environmental. But, in present scenario, there is a lot yet to exploit pine and its parts with the help of ever growing hi-tech technologies. Technological evolutions shall further extend sustainable exercise for pine forest for higher production at lower cost. It is worth to mention here that pine needles could be one of the alternate source of Shikimic acid in future. Shikimic acid is basic precursor used in the manufacturing of Tamiflu ${ }^{\circledR}$, a medicine given in the treatment of influenza and H5N1 [3]. Electricity generation from pine needles [32, 38] is believed as revolutionary invention to meet ever growing demand of electricity in future. Research reflects that medicinal applications of pine trees remain much yet to be explored. In $21^{\text {st }}$ century climate change has become a burning issue and demands of carbon credits are increasing day by day. It is challenge before us to defend pine forest for balanced survival of future generations.

In this paper, a survey summary for pine tree deforestation for hay and tendril purpose in various districts of Uttarakhand is reported. Based on the survey data, it is estimated that every year about 4 millions of pine tree are deforested in Uttarakhand. Simple calculations show that if this deforestation is avoided, it would help provide us revenue much more than what the government is generating at present from pine forest. This study proposes that preserving the hay and tendril classified deforestation of pine shall generate additional revenue of a few millions of dollars every year in near future. Besides, possible alternative solutions are proposed for hay and tendril poles purpose in order to preserve pine forest.

\section{Acknowledgements}

Government of Uttrakhand is gratefully acknowledged to provide needful data through RTI services which helped to understand economic value of pine forest. Authors are thankful to Dr. Laxmi Rawat (Forest Research Institute, Dehradun) and Mr. Rajnish Jain (Head, Avani-Bio Energy Ltd.) for much needed communication. Authors are thankful to locals and villagers who helped in field survey and in capturing pictures of hay and tendrils poles. K.E.C. Dwarahat is also acknowledged for providing needful help and support. 


\section{References}

[1] www.wikipedia.org/wiki/pinusroxburghii

[2] C. P. Kala, "Indigenous uses and structure of Chir pine forest in Uttaranchal, Himalaya, India," International Journal of Sustainable Development and World Ecology, 11(2), pp. 205-210, 2004.

[3] R. Sui, "Separation of shikimic acid from pine needles," Chemical Engineering and Technology, 31(3), pp. 469-473, 2008.

[4] S.N. Kuchimanchi, B.G.K. Murthy, P.S. Sampathkumaran, "Isomerization of Abietic acid to generate medicinally important Diterpene building blocks," American Chemical Society, Conference held at Boston, United States, pp. 18-22, 2002.

[5] J. Valnet, "The practice of aromatherapy: A classic compendium of plant medicines and their healing properties," Healing Arts Press, 1982

[6] R.N. Chopra, S.L. Nayar, I.C. Chopra, "Glossary of Indian medicinal plant,” CSIR, New Delhi, 1956.

[7] A. Puri , A.K. Srivastava, B. Singhal, S.K. Mishra, S. Srivastava, V. Lakshmi, "Antidyslipidemic and antioxidant activity of Pinus roxburghii needles," Medicinal Chemistry Research, 20 (9): pp.1589-93, 2011.

[8] B. Wiyono, S. Tachibana, D. Tinambunan, "Chemical compositions of pine resins, rosin and turpentine oil from west java," Journal of Forestry Research., 3 (1), pp.7-17, 2006.

[9] M. J. Haigh, J.S. Rawat, H.S. Bisht, "Hydrological impact of deforestation in the central Himalayas," Hydrology of Mountainous Areas (Proceedings of the Strbské Pleso Workshop, Czechoslovakia, June 1988). IAHS Publ. no. 190, 1990.

[10] R. Prabhakar, E. Somanathan, "Property regimes and deforestation: A quantitative study of the central Himalayas," Institute of Rural Management, 1999.

[11] R. Prabhakar, E. Somnathan, B.S. Mehta, "How degraded are Himalayan Forest?," Current Science, 91(1), pp. 61-67, 2006.

[12] B. Gupta, R. Mehta,V.K. Mishra. "Fire ecology of ground vegetation in Pinus roxburghii Sarg. plantation in north-west Himalayafloristic composition and species diversity," Caspian Journal of Environmental. Sciences, 7(2), pp. 71-78, 2009.

[13] D. Kaushik, A. Aggarwal, P. Kaushik, R. Mehra, A.C. Rana , "Pinus roxburghii- incredible gift in lap of Himalayas," International Journal of Pharmacognosy and Phytochemical Research, 2(2), pp. 29-35, 2010.

[14] P. Pokhriyal, G. K. Dhingra, R. Maithani, N. Panwar, N. P. Todaria, "Vegetational analysis of Pinus roxburghii forest in Uttarkashi," International Journal for Environmental Rehabilitation and Conservation, 4(1), pp.33-38, 2013.

[15] A. Farjon, "Pinus roxburghii," The IUCN Red List of Threatened Species, 2013.

[16] S. K. Ghildiyal, C. M. Sharma, S. Gairola, "Environmental variation in seed and seedling characteristics of Pinus roxburghii Sarg. from Uttarakhand India," Applied Ecology and Environmental Research, 7(2), pp. 121-129, 2009.

[17] V.A. Parasharami, S.R. Thengane, "Inter population genetic diversity analysis of Pinus roxburghii (Sarg.) from Indian provenances," International Journal of Biodiversity and Conservation, 4(5), pp. 219-227, 2012.

[18] www.oxforddictionaries.com

[19] U. Rawat, B. Srivastava, S. Semwal, O.P. Sati, “Xanthones from Pinus roxburghii,” Journal of Indian Chemical Society, 83(4), pp. 391-92, 2006

[20] M. Shuaib, M. Ali, J. Ahamad, K. J. Naquvi, M. I. Ahamad, "Pharmacognosy of Pinus roxburghii: A Review," Journal of Pharmacognosy and Phytochemistry, 2(1), pp. 262-268, 2013.

[21] M. Ahmad, S. Nazli, B. Mohammad, "Separation and analysis of sugars from Pinus roxburghii bark," Pakistan Journal of Scientific and Industrial Research, 33(12), pp. 558-60, 1990.

[22] K.R. Kirtikar, B.D. Basu, "Indian Medicinal Plants," International Book Distributors, pp. 2385-88, 1999.

[23] "The wealth of India- A dictionary of Indian raw materials and industrial products," Council of Scientific and Industrial Research, New Delhi, 2003.

[24] D. Kaushik, A. Kumar, P. Kaushik, A.C. Rana, "Analgesic and anti-inflammatory activity of Pinus roxburghii Sarg.," Advances in Pharmacological Sciences, 2012. doi:10.1155/2012/245431

www.biomassenergycentre.org.uk

www.dmmc.uk.gov.in/93-at-a-glance

www.wikipedia.org/wiki/2012_Himalayan_flash_floods

www.wikipedia.org/wiki/uttarakhand

Forest works manual-FRI under MNREGA, report, Table 1.4, (www.nerga.nic.in/1 forestWorksManual-FRI)

Dr. Laxmi Rawat, "Through private communication," Head: Ecology and Environment Dept., Forest Research Institute, Dehradun. www.ureda.uk.gov.in/142-pine-needle-based-project www.avani-kumaon.org

T.N. Bhattarai, "Charcoal and its socio-economic importance in Asia: Prospects for promotions," Regional Training on Charcoal Production, Pontianak, Indonesia, 1998.

[34] RTI communication, govt. of Uttarakhand to Gaurav Kumar Silori, Memo no. 449/22 -1(7)/3 (13-14), 2013.

[35] www.wikipedia.org/wiki/Bamboo

[36] www.wikipedia.org/wiki/shikimicacid

[37] Sundarlal Bahuguna, “Chipko Movement," www.wikipedia.org/wiki/sundarlalbahuguna

[38] Rajnish Jain, "Through private communications," Head: Avani-Bio Energy Pvt. Ltd., an NGO functioning in Uttarakhand state of India

[39] Mira Behn, "Chipko Movement", www.wikipedia.org/wiki/mirabehn, 1980-82.

[40] M. Joshi, M. Kumar, "Effect of deforestation on species composition of ground vegetation in Kumaun Himalaya, India" Ghana Journal of Forestry, 23 (NA), pp. 35-41, 2008.

[41] S.M. Nizami, S.N. Mirza, S. Livesly, S. Arndt, J. C. Fox, I.A. Khan, T. Mahmood, "Estimating carbon stocks in sub-tropical pine (Pinus roxburghii) forest of Pakistan," Pakistan Journal of Agricultural Science, 46(4), pp. 266-270, 2009. 